Georgia State University

ScholarWorks @ Georgia State University

\title{
Fragmented Legislatures and the Budget: Analyzing Presidential Democracies
}

Charles R. Hankla

Georgia State University, chankla@gsu.edu

Follow this and additional works at: https://scholarworks.gsu.edu/political_science_facpub

Part of the Political Science Commons

\section{Recommended Citation}

Hankla, Charles R., "Fragmented Legislatures and the Budget: Analyzing Presidential Democracies" (2012). Political Science Faculty Publications. 15.

https://scholarworks.gsu.edu/political_science_facpub/15

This Article is brought to you for free and open access by the Department of Political Science at ScholarWorks @ Georgia State University. It has been accepted for inclusion in Political Science Faculty Publications by an authorized administrator of ScholarWorks @ Georgia State University. For more information, please contact scholarworks@gsu.edu. 


\title{
Fragmented Legislatures and the Budget: Analyzing Presidential Democracies
}

\author{
Charles R. Hankla \\ Associate Professor \\ Department of Political Science \\ Georgia State University \\ PO Box 4069 \\ Atlanta, GA 30302-4069 \\ 404-413-6169 (T) \\ chankla@gsu.edu
}

December 5, 2012

Accepted and Forthcoming in Economics and Politics

\begin{abstract}
What impact does party fragmentation have on the likelihood of democracies to run a fiscal deficit? Past research is almost unanimous in finding that, as the number of parties in a country's legislature or government grows, so does its probability of overspending. But this finding is based largely on parliamentary systems, and there is no reason to believe that it should hold when executives are independent. In this article, I develop a theory for the impact of legislative fragmentation on budgetary politics in presidential democracies. I argue that unified presidential systems should tend most towards fiscal solvency but that increasing fragmentation should actually facilitate budget balancing when government is divided. The logic is that presidents, who are likely to prefer balanced budgets due to their broad constituencies, will be better able to craft acceptable governing coalitions from divided legislatures than from ones controlled by a single opposing party. They will also be better able to circumvent such fragmented legislatures should a coalition prove impossible. I test these propositions quantitatively in all presidential democracies from 1976 to 2007 . The results provide support for the theory and highlight the contrasting impact of legislative fragmentation on public policy in presidential versus parliamentary systems.
\end{abstract}

Acknowledgements: I would like to thank Raymond Duch, John Jackson, Rich Engstrom, Joachim Wehner, Jeff Staton, John Walson, and John Duffield for very useful thoughts on prior drafts of the paper. Thanks are also due to José Antonio Cheibub and Joachim Wehner for sharing their data with me and to Daniel Kuthy for assistance in data coding. Thanks also to the two anonymous reviewers for Economics and Politics for their insightful comments.

Keywords: presidential systems, budgets, deficits, fiscal policy, legislative-executive relations, political fragmentation, random effects, fixed effects. 
Why might a democratically elected government choose to run a sustained fiscal deficit in the face of a number of potentially serious drawbacks? ${ }^{1}$ Among the strongest findings in political economy is that fragmented polities tend to produce larger budget deficits. A multitude of studies have borne out this fragmentation-deficit relationship empirically (e.g. Roubini and Sachs 1989, Volkerink and de Haan 2001, Hallerberg and von Hagen 1999, Kontopoulos and Perotti 1999). While these studies have expanded our knowledge about the politics of budget deficits, they nearly all have one serious limitation - they ignore the unique dynamics of presidential democracy. Empirically, most analyses of political fragmentation and overspending focus on Western Europe, and thus consider few if any presidential systems. Moreover, although this is rarely acknowledged in the literature, the theoretical link between party fragmentation and deficit spending implicitly assumes a parliamentary system. In presidential systems, the executive is not drawn from the legislature, and so fragmented assemblies do not translate automatically into fragmented governments. As a result, there are very good reasons to believe that the linear relationship between divided legislatures and budget deficits may not hold for presidential democracies.

In this article, I develop and test a new theory relating governmental and legislative fragmentation to deficit spending in presidential systems. I argue that unified presidential governments (where the president and the majority of legislators are from the same party) are less likely to engage in deficit spending than divided governments. The reason is rooted in both "policy inertia" and "common pooled resource" logic; unified government empowers the president, elected from a national constituency, to rein in spending. Perhaps more surprisingly, I also contend that, when government is divided, increased legislative party fragmentation is

\footnotetext{
${ }^{1}$ The negative consequences of long-term deficits could include contracted national savings, reduced future incomes (Gale and Orszag 2003), long-term current account deficits (Yellen 1989), and the increased risk of capital flight. Short-term deficits are not thought to be problematic (e.g. Barro 1979).
} 
associated with balanced budgets. The logic is that, when legislative opposition is more fractured, presidents are in a better position to control overspending. I find support for these relationships with a cross-sectional time-series model of all presidential democracies from 19762007 (contingent on data availability). My findings force a reconsideration of budgetary politics in presidential democracies and may have implications for understanding the provision of public goods in a wide variety of policy areas.

\section{The Literature: Political Institutions and Deficit Spending}

Most studies relating fiscal profligacy to political fragmentation can be grouped into one of two branches in the literature. The first of these - termed the "policy inertia" branch by Tsebelis (2002) - argues that the presence of multiple veto points in the budget-making process slows down adjustment to fiscal shocks (e.g. Alesina and Drazen 1991, Alt and Lowry 2000, Franzese 2002). Because no party wants to reduce funding for its constituents, and because every party in a governing coalition has the power to veto spending reductions, fragmentation should produce larger deficits during hard times.

The second branch of the literature - the "common pooled resource" branch - generates similar predictions but makes a stronger claim about the relationship between fragmentation and deficits (Tsebelis 2002). Scholars in this tradition see government budgets as common pooled resources that can confront political actors with intractable collective action problems (eg. Roubini and Sachs 1989, Velasco 1997, Hallerberg and von Hagen 1999, Hallerberg 2004). In fragmented systems, the logic goes, each influential party has an incentive to direct as much spending as possible to its constituents. This is because each party internalizes all of the political rewards for spending but only part of the political costs of fiscal imbalance, which are shared 
with its coalition partners. A prisoner's dilemma therefore characterizes the budgetary process, with no party wanting a budget deficit but each unwilling to relinquish unilaterally the piece of the fiscal pie that it has won. Budgetary centralization can help overcome this collective action problem by empowering a single individual to put an end to any fiscal free riding. ${ }^{2}$

Using one or both of these logics, political scientists and economists have argued that budget deficits are more likely in countries with fragmented polities. For example, many scholars identify a relationship between budget deficits and the number of parties in coalition governments (Roubini and Sachs 1989, Volkerink and de Haan 2001, Hallerberg and von Hagen 1999, Kontopoulos and Perotti 1999, but see Hahm, Kamlet, and Mowery 1996). Focusing on another key form of fragmentation, Volkerink and de Haan (2001) find a link between the number of parties in a country's legislature and the probability that the country will run a budget deficit. Likewise, Edin and Ohlsson (1991) find that minority parliamentary governments are more likely to engage in deficit spending, while Volkerink and de Haan (2001) extend that argument to governments with very small majorities.

Of course, political fragmentation can mean something very different in parliamentary versus presidential systems. In parliamentary systems, governments must win the support of a majority of legislators to stand. As a result, party fragmentation in the assembly is normally translated into party fragmentation in the government in the form of coalitions. Likewise, when a single party controls the majority of seats in parliament (as is often the case in Westminster systems), that lack of fragmentation is normally reflected in single party government. Moreover, party discipline usually tends to empower governments in parliamentary systems (see Huber 1996); as long as the party leaders who make up the government are in agreement on fiscal

\footnotetext{
${ }^{2}$ Fiscal contracts are a plausible alternative, but these are likely to be used only under specific circumstances. See Hallerberg 2004.
} 
policy, the legislature itself is unlikely to interfere. For these reasons, relating party

fragmentation to budgetary outcomes seems quite straightforward in parliamentary systems.

Legislative fragmentation and coalition fragmentation, while not identical, are closely related and can be used as alternate measures of veto players in the budgetary process.

The situation in presidential systems can be quite different. Because legislatures and executives are elected separately in such systems, there is no necessary link between party fragmentation in assembly and government. Coalition governments are possible and indeed common in both presidential and (especially) semi-presidential systems, but the executive in these countries tends to be dominated by a powerful, single party president. As a result, in presidential and semi-presidential democracies, there is good reason to believe that predicting budget deficits requires an understanding of both legislative fragmentation and legislativeexecutive relations. The simple link between legislative fragmentation and government fragmentation observable in most parliamentary systems is simply absent.

How have scholars of political fragmentation and budget deficits dealt with differences between presidential and parliamentary systems in the past? In point of fact, the distinction has rarely been addressed theoretically. ${ }^{3}$ The most common practice has been to make the broad veto players or common pooled resource argument in studies of both government and legislative fragmentation, and to translate that directly into expectations about budget balances. Such an approach makes sense when studying parliamentary systems, where legislative and executive power is fused, but it can create problems when applied to presidential democracies. Measuring fragmentation in such systems with the effective number of parties in the legislature ignores the existence of a separately elected, single party executive. On the other hand, considering

\footnotetext{
${ }^{3}$ A rare exception is Alt and Lowry (2000), who find that in US states (which are "presidential" in structure), divided government slows adjustment to fiscal shocks. Another is Cheibub (2006), who finds that the presidential parliamentary distinction matters for deficits, but that the nature of legislative coalitions does not.
} 
presidential systems as having no fragmentation because of their executive institutions underrates the importance of their sometimes fractious legislatures.

If most of the theory developed in the literature is best suited to understanding parliamentary systems, what of the empirical analyses? Scholars of fragmentation and budgetary politics have mostly pooled the two types of systems and simply coded presidential democracies based on the fragmentation of their legislatures (e.g. Grilli, Masciandaro, and Tabellini 1991, Volkerink and de Haan 2001) or governments (e.g. Kontopolous and Perotti 1994, Perotti and Kontopolous 2002, Hallerberg and Von Hagen 1999, Hallerberg 2004). To take a prominent example, Roubini and Sachs (1989) pool cases from the two systems by coding unified presidential systems as identical to single party parliamentary cases and divided presidential systems as the same as coalition parliamentary systems. As already noted, the budgetary process is likely to differ significantly across these cases, calling into question such an approach.

Why has much of the literature that has pooled presidential and parliamentary systems found evidence of a linear link between legislative or governmental fragmentation and budgetary outcomes? Most of these studies use datasets dominated by parliamentary systems, with the United States, France, and Finland often the only cases with popularly elected, powerful presidents. ${ }^{4}$ It seems possible, therefore, that these results are uncovering a genuine relationship between fragmentation and budget deficits in parliamentary systems, which constitute the bulk of their datasets. In addition, even in presidential systems, lower fragmentation manifested in unified government should be associated with balance budgets, but, as I argue here, that is far from the whole story.

\footnotetext{
${ }^{4}$ And note that the president does not tend to be a dominant player in the budgetary process in France and, especially, Finland. As discussed below, semi-presidential systems such as these are not included in my empirical analysis.
} 
While scholars have not fully examined the link between political fragmentation and budget deficits in presidential systems, some have sought to explain overspending in these systems with other institutional variables. For example, Franzese (2002) and Cheibub (2006) argue that presidential democracy itself makes states less prone to deficit spending than parliamentary democracy because it empowers an executive with a national constituency and clear responsibility for budgetary decisions. Persson and Tabellini (2003), however, find that the presidential / parliamentary distinction has no impact. In a similar vein, Hallerberg and Marier (2004) show that, in Latin American presidential systems, a strong executive is necessary to tame legislative spending when party and electoral rules provide an "incentive to cultivate a personal vote". Finally, Stein, Talvi, and Grisanti (1999) find a weak relationship between district magnitude and budget deficits in Latin American presidential systems.

Research into the political determinants of other economic policies has also addressed legislative-executive relations in presidential systems. For example, O'Halloran (1994) has associated unified presidential government with free trade policies, although this argument has more recently been challenged by Karol (2000). Nooruddin (2011) has found evidence that divided presidentialism (in contrast to coalition parliamentarism) can impede the stability of economic growth. And closer to our area of concern, Lienert (1997) has examined the crossnational relationship between presidentialism and legislative power over the budget. Numerous scholars have also identified the detrimental effects of divided presidential government for legislative-executive cooperation and public goods provision in specific national and regional contexts (e.g. Jones 1995, González and Gillespie 1994).

To summarize, most of the budget literature pools presidential and parliamentary democracies, leaving budgetary politics within presidential systems seriously understudied. To

\footnotetext{
${ }^{5}$ This concept was developed and measured by Carey and Shugart 1995.
} 
the extent that presidential systems are specifically considered in the budget literature, it is almost always to contrast these systems with parliamentary systems rather than to examine the internal dynamics of presidential government. Further, while a few scholars have produced clear arguments about the effects of divided versus unified presidential systems in public goods provision, even here there is little attention to the effects that legislative fragmentation might have on policy outcomes. In the next section, therefore, I will seek to develop a comprehensive theory of budgetary politics in presidential democracies that will plug this hole in the literature.

\section{Theory}

Before launching into developing my theory, it is useful to define the terms and to identify the assumptions that I will be using in this paper. Following Cheibub (2007), I define a system as pure presidential if (1) the president cannot be removed by the legislature and, (2) the government is responsible to the president. The assembly is also unable to remove the president in a semi-presidential system, but in such systems the government is responsible to both president and assembly. Finally, in a parliamentary system, the assembly is empowered to remove the government.

Typically, presidents are either popularly elected or elected by a representative electoral college. However, in some counties they are elected by the assembly, which is then unable to remove them from office (except through impeachment). Because the assembly's powerlessness to bring down the government is the key characteristic of presidentialism, I follow Cheibub (2007) by classifying such systems as presidential and including them in my analysis. However, I do not consider semi-presidential systems in this article. While the budgetary dynamics found in semi-presidential systems will likely differ from those found in parliamentary systems, the 
presence of a government drawn from the assembly distinguishes these systems significantly from pure presidentialism. As I result, I am not convinced that my theory will describe their behavior accurately. Finally, I make the assumption that budgetary approval requires the assent of fifty percent of the legislature. While presidents in different countries have differing authority over the budgetary process, as we will discuss later, legislative approval is generally required (see Wehner 2006).

I develop here a theory relating political fragmentation to budget deficits that is specific to the context of presidential democracies. In doing so, I take into account both elements of fragmentation that can be important in such systems - the relationship between the legislature and the executive and the partisan composition of the assembly. My argument is that both of these components must be considered in order to develop a truly comprehensive understanding of how political differences affect spending decisions in presidential democracies.

Beginning with the relationship between presidents and assemblies, I argue that unified governments will generally be better able to balance their budgets than divided governments. A unified government, of course, is one where the presidency and the majority of seats in the assembly are both held by the same political party, and a divided government is one where either a different party or no party holds the majority. Why should unified government encourage balanced budgets? The reasons are rooted in both the "policy inertia" and "common pooled resource" branches of the deficit literature. Unified government should overcome the policy inertia that may delay fiscal adjustment by reducing the effective number of veto players with influence over the budget. When a single party dominates both the executive and legislative branches, fewer actors are able to veto any spending reductions that may be compelled by exogenous shocks. 
Moreover, unified government should reduce the common pooled resource problem that is at the heart of fiscal profligacy. Overspending may benefit certain locales within a country, but the budget deficits that it can produce threaten national economic well-being. Presidents, more than legislators, have incentives to promote balanced budgets because of their national constituencies. While presidents may support allocating government spending to social groups that support their parties, their concern for broader public goods is likely to be stronger than those of legislators, who must answer to their local constituents.

This greater concern for fiscal balances is likely to be true of presidents generally, but it is only when government is unified that they will also have the political power necessary to impose their preferences on the assembly. When a president is the senior member of the party controlling the legislature, she can use her influence to rein in unreasonable spending requests from co-partisan lawmakers. As a result, I expect that unified presidential governments will have smaller budget deficits (or larger surpluses) than divided presidential governments, other things equal.

What, then, should be the impact of legislative fragmentation on budgetary outcomes in presidential democracies? When government is unified, I argue, legislative fragmentation is unlikely to matter very much. If the president's party controls the majority of seats in the assembly, whether the remaining seats are held by one party or one hundred parties should not be terribly important. As long as majority control is all that is necessary to dominant the budget process, which is generally but not universally true, crossing that $50 \%$ threshold should be the key factor.

The calculation changes, however, when the president's party fails to reach that threshold. When government is divided, the president and her party must reach out to other 
parties to gain the votes necessary to approve the state budget. Under these conditions, therefore, the partisan structure of the opposition can matter quite significantly. But how does it matter?

I argue here that, contrary to what one might expect, increased legislative fragmentation under conditions of divided presidential government will contribute to balanced budgets. In other words, when government is divided, fragmentation in presidential systems will tend to have the opposite impact on deficit spending as it seems to in parliamentary systems. Of course, fiscal responsibility is most likely to obtain when presidential governments are unified, but, when the two branches are controlled by different parties, it is better for the legislature to be fragmented. This seemingly paradoxical argument stems from the observation that presidential influence over the budget process is likely to be maximized when the opposition is divided rather than when it is centered in a single party. Because, as discussed above, presidents should (other things equal) value fiscal responsibility more highly than legislators, and because the reduced power of opposition parties reduces the number of veto players impeding policy change, this empowerment should contribute to balanced budgets.

Why do fragmented legislatures contribute to the influence of presidents, and therefore more balanced budgets, when government is divided? First, when there are multiple opposition parties, it tends to be easier for presidents to form coalition governments with policy buy-in. In pure presidential systems, of course, governments are responsible only to the president. Frequently, however, presidents choose to form coalition governments in order to curry the legislative support that they need for their initiatives. These coalition presidential governments are most commonly observed when legislative fragmentation is high (see Cheibub 2007).

To see why, imagine a president's task in forming a government when a single party forms the opposition. In such a circumstance, it is unlikely that the opposition party, which 
controls the assembly and is likely biding its time to make a bid for the presidency, will agree to join or even support the government. All of the party's incentives point it towards acting as a spoiler for the government. By contrast, when the opposition is made up of a multitude of smaller parties, it should be significantly easier for the president to entice some into a coalition. Some of these parties may have similar policy preferences to the president's party, and, moreover, they have much less to gain by opposing the president in the legislature. Smaller parties are likely to find real policy influence and government portfolios too tempting to resist. Why, then, should a president's ability to entice minority parties into her coalition contribute to fiscal responsibility? When the alternative is divided and minority government, coalition government has a number of advantages for the budgetary process. Most especially, non-presidential parties, by associating themselves with the government, expose themselves to popular approbation if their fiscal profligacy should damage the economy. In exchange for access to power, they also recognize to some extent the leadership of the president and surrender the freedom to publicly criticize her. As a result, when the budget comes up for legislative approval, they may have little choice but to support it. That may be the reason that Edin and Ohlsson (1991) find that, in parliamentary systems, minority governments are the most likely of all to engage in overspending.

Of course, non-presidential parties that hold portfolios can seek to direct public resources to their constituencies during the formation of the budget, and no doubt they often do. There is also the possibility that parties may threaten to leave the president's coalition (or not to join it in the first place) if not given favorable fiscal terms. Such behavior, however, is unlikely to result in fiscal profligacy to the degree that would obtain under low fragmentation divided government. One way to see this is to imagine the opposition party's leverage in market terms; threats of 
leaving the coalition will likely produce some fiscal success for an opposition party under high fragmentation divided government, increasing the chances of large deficits from what we would see in a unified system. That said, the party's threat to exit the cabinet will lack the credibility of a threat made by a much larger opposition party in a system of low fragmentation. This is because the party leaders will understand that if they push too hard for fiscal benefits, the president can replace them in the cabinet with another party. They would then lose the benefits of controlling a portfolio and would become one of many opposition parties in the legislature. By contrast, large opposition parties under low fragmentation divided government are indispensable; their support must be obtained to move the legislative agenda forward. As a result, whether they join the president's coalition or not, such parties have more power to demand fiscal benefits for their constituents.

For similar reasons, a fragmented legislature and divided opposition can strengthen the president's hand in the budget process even when she does not successfully seek coalition partners. When government is divided and one or two major opposition parties control the majority of seats in the assembly, a president will be left with no alternative but to placate their fiscal demands. The budget process will therefore no longer be dominated by a single executive with a national constituency who internalizes politically the dangers of overspending. However, when opposition is divided among multiple parties, a president can adopt some additional strategies to gain legislative approval of the budget. First and foremost, when the president enjoys the right to propose the budget, as is frequently the case, a divided legislative will allow her more options about where to set the terms of the debate. This is because there are more possible legislative coalitions that could be formed to support the proposal. As a result, when faced with a divided legislature, a president can strategically propose the budget to produce an 
outcome that will minimally deviate from her preferences. Not only that, but a divided opposition should facilitate the president's use of her constitutional powers. In other words, an opposition made up of multiple disputing parties is unlikely to interfere effectively with a president's use of agenda setting and decree powers (see Carey and Shugart 1998). By contrast, when a single opposition party controls the legislature, the president is faced with fewer options (assuming that party discipline holds). Presidents can also play smaller opposition parties against one another to achieve preferred outcomes and to keep the budget in check. Again, a useful analogy may be a market system; the greater the supply of parties that can be cobbled together to form a legislative coalition, the lower the cost in private goods necessary to purchase each party's support. Of course, more parties that must be placated mean a wider variety of fiscal demands, and unified government is the most likely institutional configuration to promote balanced budgets. When government is divided, however, divide-and-conquer tactics from the president can strengthen her hand in a fragmented legislature.

As noted above, my argument for the impact of unified and divided government on budgetary outcomes in presidential democracy gels with most of the extent literature. My expectations concerning the influence of legislative fragmentation on budgetary outcomes under conditions of divided government, however, may seem more puzzling. Linz (1990) and others have long argued that the presidentialism is dangerous for the survival of democracy. Moreover, Mainwaring (1993) has identified the combination of presidentialism and multipartism as especially noxious for the stability of emerging democracies. He fears that fragmented legislatures, lacking the incentives for compromise that government formation creates in parliamentary systems, will lead to gridlock and democratic collapse. Mainwaring would agree 
on the beneficial effects of unified government, but he cautions against the very condition that I find helpful for budget balances under divided government, namely multiparty legislatures. ${ }^{6}$

How can we explain these seemingly contradictory findings? Mainwaring argues that multipartism impedes compromise in presidential systems, threatening their durability. This argument is broadly compatible with mine, insofar as I draw a connection between unified presidential government, which will be more common under two-party systems, and balanced budgets. We part company, however, when I argue that fragmentation contributes to balanced budgets (and perhaps public goods provision more broadly) when government is already divided. To put the issue differently, Mainwaring draws an essentially linear connection between fragmentation and negative outcomes, while I draw a non-linear connection.

My point is that, under the less-than-ideal conditions of divided government, presidential authority will be greater when the opposition is fragmented. In a sense, this authority will contribute to more compromise between the executive and the assembly, as it provides small opposition parties more incentives to follow the president's agenda. But it also makes it easier for the president to roll over opposition parties should that become necessary. To the extent, then, that presidents represent the national interest, a fragmented opposition is better than a unified opposition under divided government.

That said, it is possible to overstate the differences between my argument and that of Mainwaring. He is considering a related but distinct dependent variable from mine - that of regime durability. It may well be that the same institutions that allow presidents to dominate the assembly also impede the fair representation of relevant interest groups within society. Such a situation might ultimately weaken the legitimacy of a regime, even as it makes its policy-making

\footnotetext{
${ }^{6}$ Note, however, that Cheibub 2007 contests the view that gridlock and other structural flaws in presidential systems contribute to their greater rate of democratic collapse.
} 
more efficient. Of course, this logic is somewhat different from the one that Mainwaring relies on in his argument, but it is hinted at by Linz in his discussion of the dangers of majoritarianism.

Other findings in the literature bear more directly on the question of public goods provision in presidential systems. Mainwaring also argues elsewhere (1999) that fragmented legislatures in Brazil impeded economic reform. On a similar note, and in the piece perhaps closest to addressing my question here, Stein, Talvi, and Grisanti (1999) find that increased district magnitude, associated with multiparty legislatures, contributes to budget deficits in presidential systems. In these cases, I suspect that that the findings are driven by the benefits of unified government over divided government, which I do not question. As noted above, the effects of party fragmentation under divided government have never been independently tested, and that is one of my primary goals here.

\section{Conditions and Caveats of the Argument}

The logic of my argument assumes that both legislatures on the one hand and political parties on the other are strong enough to mean something in the budgetary process. To begin with the first of these issues, presidents in different systems can have wildly contrasting powers vis-à-vis legislatures over policy and the budget process (Shugart and Carey 1992). Scholars of the fiscal process have already demonstrated the importance of executive power for budgetary outcomes in parliamentary systems. Taking as their starting point the policy inertia or common pooled resource logics, these political economists have found evidence that budget deficits are higher when there are more spending ministers in a country's cabinet (Kontopoulos and Perotti 1999, Volkerink and de Haan 2001) and when finance ministers are weak (Hahm, Kamlet, and Mowery 1996). 
Among presidential democracies, the role of the president in the fiscal process can also have important implications for budgetary outcomes. In some countries, for example, presidents have the sole authority to present the budget, while in others that responsibility resides with the assembly. In some countries, the president's status quo preference becomes law unless the assembly actively objects, while in others the president's primary budgetary power is the veto pen (Wehner 2006). To take a specific example of how presidential powers might matter for budgetary outcomes, Baldez and Carey (1999) have shown that in Chile, where the legacy of authoritarianism has left the president with unusually wide-ranging powers, budgets are generally balanced. As one would expect, the dominance of a president who internalizes the costs of fiscal irresponsibility has allowed Chile to avoid deficit spending.

The bottom line for our purposes is that when national constitutions endow presidents with significant decree powers, the importance of legislative structure is diminished. Because legislative fragmentation only matters to the extent that legislatures matter, my argument makes less sense in countries where the budgetary process is dominated by powerful presidents. As a result, I use two separate indices to control for presidential versus legislative budgetary powers. I also estimate a model considering only those countries with a modicum of legislative power.

A second important condition of my argument concerns the strength and centralization of party institutions. As Hallerberg and Marier (2004) have convincingly shown, party centralization can substitute for executive power in centralizing decision-making in the hands of party leaders with national constituencies. It should therefore be associated with balanced budgets and surpluses. Moreover, the importance of unified government, central to my theory, is at least partially dependent on the existence of party discipline. If parties are mere paper tigers, unified government will not truly strengthen the hand of the president. As a result, the impact of 
unified government is likely to be less in weak party systems such as Brazil than in strong party systems such as Chile (see Mainwaring 1999). Not only that, but when party organizations are less able to exercise discipline over legislators, the concept of partisan fragmentation has less meaning. As I result, I control for party decentralization in my primary models, and I also estimate a model that considers only those country-years where parties are centralized.

My argument only represents tendencies of cause and effect generally observable across cases and must depend on a very clear assumption of "other things equal". In addition to the two conditions discussed above, there are two other potentially confounding factors that are not considered in the theory but that will be controlled for in the empirical model.

My argument focuses on legislative-executive relations and party fragmentation, but does not consider the ideological distance between parties. In other words, I am concerned with the number of parties but not with their relative placement along the ideological spectrum. I take this focus primarily for practical reasons and for parsimony; the impact of ideological space can be quite complex and would be difficult to include in an empirical model (see Cheibub 2007). ${ }^{7}$ However, I do make an effort to control for partisan ideology in my empirical model, discussed below.

A second caveat relates to the varying electoral systems of presidential democracies. Some scholars, especially in the trade literature, have suggested that electoral constituency size is the key determinant of public goods provision. For example, Rogowski (1987) argues that democracies that depend on open trade will tend to combine parliamentary systems with large, proportional electoral districts. The logic is that, when legislative constituencies are large, the preferences of representatives will tend more towards the public interest, ensuring that trade

\footnotetext{
${ }^{7}$ Krause (2000) analyzes ideological differences within and across parties in the US case, and finds that these differences are a predictor of budget deficits. Such an approach is powerful but would be very difficult to execute in a cross-national context.
} 
remains open. Providing potential support for this logic, Stein, Talvi, and Grisanti (1999) and Persson and Tabellini (2003) find an association between proportional representation and balanced budgets.

Constituency size and legislative fragmentation are associated with one another through their common relationship with electoral district magnitude. Countries with large district magnitudes, a measure of the number of representatives elected from each constituency, will tend to have both more parties and larger electoral districts. As a result, to ensure that legislative fragmentation and not electoral district size is explaining deficit spending, I include a variable measuring electoral system in the empirical models.

\section{Data and Methods}

I test my argument with a broad dataset that includes all presidential democracies from 1976 to the $2007 .{ }^{8}$ Country-years are included in the model when states have a Polity score greater than "5", indicating that they are democracies (Marshall and Jaggers 2007), and when they are coded as presidential (or as assembly-elected presidential) using the "system" variable developed by Beck et al. (2001). My presidential models consider between 345 and 636 observations -47 countries for an average of 13 years each for the primary model. ${ }^{9}$

Examining all presidential democracies for which data are available, and across a reasonably wide swath of time, is, I believe, an important empirical contribution to the literature. Most studies of the political economy of deficit spending have focused on the OECD countries, a group consisting primarily of rich democracies with parliamentary institutions. ${ }^{10}$ Those few that

\footnotetext{
${ }^{8}$ Data and replication instructions are available upon request from the author.

${ }^{9}$ While the observations included in the models are restricted due to data availability, the number of observations included is actually quite comprehensive considering that only presidential democracies are analyzed.

${ }^{10}$ An important exception is Persson and Tabellini 2003.
} 
have considered presidential democracies have looked almost invariably to Latin America, excluding such systems in Africa and elsewhere (e.g. Hallerberg and Marier 2004). My broader empirical examination provides a more extensive test of the generalizability of my theory than would a more geographically limited study. It also allows me the opportunity to say something preliminary about the global relevance of other explanations common in the literature. I list the country-years included in my primary model (Model 1) in Table 1.

\section{Insert Table 1}

For my dependent variable, I make use of each country's total national budget balance divided by its gross domestic product (GDP) and multiplied by one hundred. A positive budget balance is of course a surplus, and a negative balance a deficit. In order to maximize the number of observations available, I begin coding the variable using World Bank (2008) budget balance data in current local currency units, and then, when observations are missing, supplement the variable with data from IMF (2011) and finally with data from IMF (2006). I then standardize the raw budget balance data by dividing it by GDP in current local currency units for each country-year (also from World Bank 2008). In estimating my models, I drop the small number of observations where a country's budget deficit or surplus exceeds $20 \%$ of GDP. These outliers reflect either flaws in the source data or countries in unusual economic circumstances (whether crises or booms). Note that, for robustness, I also run my models with the budget balance data used by Cheibub (2006), which draws exclusively from the World Bank and is thus coded for fewer country-years.

Because the theory predicts that increased party fragmentation should improve budget balances in presidential democracies only when government is divided, my primary independent variable is interactive. I operationalize this interaction in three distinct ways. For ease of 
interpretation, I use two dummy variables for the primary models, each taken from Beck et al. (2001); the first (Divided Government High Fractionalization) is coded "1" when the government is divided and the lower house of the legislature is highly fragmented, and the second (Unified Government) is coded "1" when government is unified. The reference category, then, in made up of systems with divided government and low legislative fragmentation. My expectation, of course, is that both Divided Government High Fractionalization and Unified Government will have a positive and significant impact on budget balance vis-à-vis divided, low fragmentation systems.

I operationalize the Unified Government variable, which I also use to help code Divided Government High Fractionalization, with the "allhouse" variable from Beck et al. (2001), which is itself coded " 1 " when the party of the executive controls all relevant houses of the legislature. While my argument has focused primarily on the lower legislative house, presidential party control in a powerful upper house could impact budget balances in unpredictable ways. The "allhouse" variable allows me to consider the role of fragmentation in purely divided systems. To operationalize high fragmentation, I make use of the "frac" variable from Beck et al. (2001), which is coded as the probability that any two randomly drawn legislators from the lower house come from different parties (a concept called legislative fractionalization). For that reason, a single party legislature would receive a "frac" score of " 0 ", while a legislature where every member belonged to a different party would be coded “1”. I select .667 as my cut-off point because it translates into a system with three or more "effective parties" (see Laakso and Taagepera 1979).

For robustness, I also use data from Henisz (2003) to generate dummy variables equivalent to those above. Because the Henisz (2003) data do not contain an indicator of unified 
government identical to the Beck et al. (2001) "allhouse" variable, I generate my own - Unified Government 2. I set this variable equal to "1" when the Henisz (2003) variables "Align E_L1" and "Align E_L2" indicate that the party of the executive controls both the lower and upper houses of the legislature. If the variable "L2" indicates that a country's upper house lacks power, I consider only executive alignment with the lower house in coding the variable. I then create Divided Government High Fractionalization 2 using this new variable and the Henisz (2003) legislative fractionalization variable "Legfra Lower". Note that Divided Government High Fractionalization 2 and Divided Government High Fractionalization correlate at the relatively low level of .436, and so if the results are robust to both operationalizations, it will be strong evidence for my theory. ${ }^{11}$

My final approach to operationalizing the primary independent variables is to use a full interaction term. The advantage of this approach is that it allows for a more complete modeling of the conditional effect of each component of the interaction at different levels of the other component. The drawback is that this approach can be harder to interpret; to remedy that problem, I have included graphical representations of the results of my interactive model. To measure the first component of the interaction term, I make use of Unified Government, as described above. For the second component, I employ Legislative Fractionalization, the "frac" variable from Beck et al. (2001), to operationalize legislative party fragmentation in the lower house.

In addition to these primary independent variables, I include a series of political control variables in the models to address each of the two conditions and two caveats discussed in the

\footnotetext{
${ }^{11}$ Note that the "Align E_L1" and "Align E_L2" are coded "1" when the party of the executive holds the majority in the chamber and (unlike with "allhouse") when it is a member of the ruling coalition in that chamber. This difference likely helps account for the relative low correlation between the variables calculated from Beck et al. (2001) and Henisz (2003).
} 
previous section. First, I operationalize party decentralization as the "ballot" variable introduced by Carey and Shugart (1995) to explain a legislator's “incentive to cultivate a personal vote.” My variable Party Decentralization is coded " 2 " when party leaders have almost no control over ballot access (as in, for example, primary systems), “1” when they enjoy control over ballot access but voters can reorder the electoral list (as in, for example, open list systems), and " 0 " when they exercise almost complete control over nomination. I code my party decentralization variable across countries (all democracies) and years (1975-2005), and I expect it to be negatively associated with budget surpluses. ${ }^{12}$

In order to operationalize the constitutional budgetary authority enjoyed by presidents versus legislatures, I borrow the presidential dominance (Presidential Dominance) variable developed by Cheibub (2006) and the legislative budgetary powers (Legislative Budgetary Powers) variable developed by Wehner (2010). The Cheibub variable is a dummy coded "1" when presidents dominate the budgetary process; this situation obtains, for example, when presidents initiate the budget and legislatures have limited amendment power. The Wehner variable ranges from " 0 " to " 1 " and measures the extent to which legislatures have influence over the budgetary process. Legislatures at the weak extreme, coded "0", are only able to take an up or down vote on an executive proposed budget; those at the other extreme, coded " 1 ", have no significant limitations on their budgetary role. As both variables are only available for a portion of the country-years included in my model, I estimate my primary models without them and include them in separate robustness tests. Because stronger presidents can overcome the common pooled resource problem of budgetary politics, I expect the Presidential Dominance variable to be positively related to surpluses and the Legislative Budgetary Power variable to be negatively related to surpluses.

\footnotetext{
12 The coding procedure is described in Hankla 2006.
} 
To control for a country's electoral system, I include in the analysis a dummy variable (Plurality Electoral System) coded "1" for plurality systems in the lower house and taken from Beck et al. (2001). Finally, to test for the importance of ideology on deficit outcome, I include a dummy variable coded "1" in the presence of a leftist governing party (Leftist Government), also taken from Beck et al. (2001).

Beyond these four independent variables included to address my theoretical conditions and caveats, I make use of one additional political control. To test for the presence of a politicalbusiness cycle in deficit spending, I introduce a variable coded " 1 " if an election occurs in that year (Election Year), using data from Beck et al. (2001). If governments are spending more to reduce unemployment and improve growth immediately prior to elections, we would expect them to tighten their belts immediately afterwards. As this variable is lagged, it measures the impact of having an election in one year on the following year's finances; we would therefore expect it to be positive and significant.

I also include in the analysis a series of economic variables. I control for a country's development status with its logged GDP per capita (Logged GDP per capita) and for its potential welfare burden with the percentage of its population over 64 years old (Pop over 64). Richer countries should have more balanced budgets, other things equal, while countries with older populations may overspend. Further, I use a variable measuring each country's annual percentage change in GDP to control for economic shocks $(\triangle G D P)$. Governments may feel the need to run fiscal imbalances during economic crises to stimulate their economies. I also include in the model annual percentage change in each country's exchange rate with the United States dollar ( $\triangle$ Exchange Rate). A stronger currency should make government purchasing cheaper, potentially improving budget balances, and it may also be an indicator of tighter fiscal policies. 
At the same time, however, a weaker currency may reduce a country's debt burden. Finally, to control for the government's role in the national economy, I employ a variable measuring the percentage of a country's GDP taken up by government consumption (Govt Consumption / $G D P)$. This variable is likely to be negatively related to surpluses because larger governments have greater potential to overspend in significant amounts. Data for all of these variables are taken from World Bank (2008). I lag all of my independent variables and summarize their characteristics and their expected relationships with budget surplus in Table 2.

\section{Insert Table 2}

Given the nature of my data, I estimate my models using OLS regression with panel corrected standard errors, a lagged dependent variable, and dummy variables for world regions. The panel corrected standard errors approach allows me to leverage the robustness of OLS regression while taking the country panels in the data into consideration in the computation of my standard errors. The lagged dependent variable deals with the first-order autocorrelation in the models, and is the approach recommended by Beck and Katz (1995), while the region dummies control for cultural and learning factors that may prevail in different parts of the world. Note that there is no need to difference the dependent variable because it is stationary for the large proportion of country panels, as evidenced by a Fisher unit root test (xtfisher in Stata). ${ }^{13}$

Another approach - fixed effects regression - reduces omitted variable bias by including country dummies, but it also washes out much of my interesting variation by focusing on within country, cross-temporal variation at the expense of cross-national variation. ${ }^{14}$ For robustness, I also estimate my models using this approach. Finally, I make use of "robust regression" (rreg in Stata) to control for the effects of the many outliers and extreme values in my dataset. This

\footnotetext{
${ }^{13}$ See Maddala and Wu 1999. This approach allows me to test for a unit root in my unbalanced panel data, unlike a traditional Dickey-Fuller test.

${ }^{14}$ For more on fixed effects models, see Green 2007.
} 
approach calculates Cook's D, a statistic which measures the influence of each observation on the results, and then iteratively corrects for the most influential observations by weighting or even dropping them from the model. If my results hold up to robust regression, it will provide strong evidence that they are not driven by a small number of influential country-years.

\section{Results}

My primary model, the first model in Table 3, provides strong support for the theory. Both Divided Government High Fractionalization and Unified Government are in the expected direction and significant at the $1 \%$ level, indicating that, in presidential systems, unified government and divided government with a fragmented legislature are better for fiscal solvency than divided government with a more unified legislative opposition. The coefficients suggest that a move from divided government with low fragmentation either to unified government or to a more fragmented legislature will tend to improve the budget balance by nearly one percentage point, an important effect. Note also that the predicted effect of moving to unified government or to divided government with a fragmented legislature is roughly the same, indicating that both alternate institutional configurations provide about the same potential benefit to government finances.

\section{Insert Table 3}

These results are largely echoed by the remaining models presented in Table 3. Model 2, which estimates the primary model using robust regression to reduce the power of influential observations, produces only slightly weaker and still highly significant results for the primary independent variables. The coefficient for Unified Government in Model 3, which uses the fixed effects estimator, remains statistically significant in the expected direction, while the coefficient 
for Divided Government High Fractionalization is just shy of a standard level of significance $(\mathrm{p}=.129)$. Given that the fixed effects estimator considers only the less notable within-country variation in the independent variables, a weakening of the results is not surprising. That said, the continuing significance of one of the two dummies, and the near significance of the other suggests that the results of the primary model are not merely a function of omitted variable bias.

Model 4 uses an interactive variable to estimate more fully the relationship between unified government, legislative fractionalization, and the budget. The conditional impact of unified government and party fractionalization on budget surpluses is most clearly seen in Figures 1 and 2, both of which are computed from this model. Figure 1 shows the effect of unified government on budget surpluses at different levels of legislative fractionalization. The solid line represents the estimated effect and the dotted lines are the $95 \%$ confidence intervals. The figure shows that unified government, as expected, has a significantly positive impact on surpluses until about 0.65 fractionalization, at which point the effect becomes insignificant. Why does the effect of unified government decline and eventually lapse into insignificance when legislative fractionalization is high? One possible explanation points to the fact that there are few observations in which government is unified and legislative fractionalization is high. Such a confluence would require a minority opposition of numerous small parties, and there are probably not enough observations to estimate the impact of unified government under these rare conditions.

Another possible explanation, supported by the results above, is that, when legislative fractionalization is high enough, it is equally good for the fiscal balance to have divided government as to have unified government. In other words, the benefits of a highly divided 
opposition may be so great that the president can control the budgetary process as effectively as if government were unified.

\section{Insert Figure 1}

Figure 2 shows the flip side of the interactive term - the effect of a one unit change in legislative fractionalization when government is unified and when it is divided. ${ }^{15}$ As expected, legislative fractionalization is positively related to budget surpluses when government is divided, and it has no discernible impact when government is unified.

In addition to being statistically significant, the conditional effects of unified government and legislative fractionalization on budget balances are substantively important. When legislative fractionalization is held at its minimum, moving from divided to unified government improves the budget balance, on average, by more than one standard deviation, about 3.5 percentage points. Likewise, under conditions of divided government, moving from a single party to a perfectly fractionalized legislature produces an improvement in budget balances of well above one standard deviation or about 4.7 percentage points.

\section{Insert Figure 2}

I estimate the primary model with the Party Decentralization variable in Model 5. The primary results largely hold up, although the Divided Government High Fractionalization dummy falls just below significance. It is interesting also to note that the party decentralization variable is strongly significant in the expected direction, providing evidence consistent with Hallerberg and Marier (2004) that systems with more decentralized parties tend to run higher deficits.

\footnotetext{
${ }^{15}$ Each of these effects is linear, such that the effect of a half unit change in legislative fragmentation on budget surpluses for unified versus divided government is half of the coefficient. The lines represent $95 \%$ confidence intervals.
} 
The final two models in Table 3 include the two variables controlling for presidential versus legislative budget powers in different systems - Wehner's Legislative Budget Power and Cheibub's Presidential Dominance. The inclusion of each of these variables reduces the number of observations significantly, but the primary results still largely hold. It is also interesting to note that both variables are strongly significant in the expected directions, suggesting that countries with more powerful legislatures do tend to have more budget deficits.

Turning now to Table 4, Model 8 presents the primary model without the economic control variables that include GDP in their calculations. The purpose here is to avoid any endogeneity with the dependent variable, and it is clear that the results continue to hold. Model 9 makes use of Budgbal, the operationalization of the dependent variable used by Cheibub (2006) and taken solely from the World Bank. While this model drops more than 200 observations, the results largely hold, especially for Divided Government High Fractionalization.

\section{Insert Table 4}

Models 10 and 11 present analyses patterned after the primary model (Model 1), but considering only those country-years that meet certain conditions. The first of these models is limited to those democracies characterized by powerful legislatures, defined as those scoring above a "0" on Wehner's Legislative Budgetary Power scale. The logic here is that, when presidents are completely dominant in the budgetary process, legislative-executive relations are unlikely to matter. The second model is limited to democracies with centralized parties, defined as those country-years coded "0" for Party Decentralization. I set this condition because, as discussed above, the theory depends on the existence of meaningful political parties.

The results of Model 10 are significantly strengthened by the exclusion of systems with weak legislatures; this finding is not unexpected given that the theory assumes the importance of 
both executive and legislature in the budgetary process. Somewhat surprisingly, however, the results of Model 11 are weaker than those of the primary model, with both variables approaching standard levels of significance but not quite achieving them. This result may simply be due to the numerous observations dropped by the model, or it may reflect the fact that parties continue to matter even in systems (like the United States) where they are relatively decentralized.

In Model 12, I make use of the two alternative operationalizations of my primary variables - Unified Government 2 and Divided Government High Fractionalization 2 - both of which are computed from Henisz (2003). Strikingly, despite the low correlation between these variables and those used in the primary models, the results hold to a high level of significance. It is interesting, however, that the Divided Government High Fractionalization variable is predicted to have a greater impact on the budget balance in these models. ${ }^{16}$

The control variables in each of the models are largely as anticipated. Leftist governments are found to run larger surpluses in one of the models, but otherwise ideology does not seem to be a major predictor of fiscal performance. This finding supports Hahm, Kamlet, and Mowery (1996), who find that governing ideology is unrelated to fiscal discipline. The Government Consumption / GDP variable is significantly related to budgetary outcomes in only one of the models, indicating that larger governments may be more likely to run deficits but that government size is not the most important factor in overspending. The Plurality Electoral

\footnotetext{
${ }^{16}$ To ensure that my findings are not driven by any one part of the world, I also estimate the primary model after dropping each of the world regions (not shown here for space reasons), and the results are largely unchanged. Both variables remain significant throughout, with the only exception that Divided Government High Fractionalization drops slightly below significance when South American countries (the plurality of my dataset) are excluded. Note also that I estimate a model using a third operationalization of the primary variables. This one also derives from Henisz (2003) and is computed by comparing the name of the ruling executive party with the name of the primary party in the legislature. If those names match, and if the legislative party controls a majority of seats, I code the variable "1". Models using this operationalization produce results in the expected direction for both variables, with Divided Government High Fractionalization just shy of statistical significance and Unified Government not significant. Running the same model using fixed effects, however, raises the first of the variables to strong significance and the second to a p-value of .103.
} 
System variable is associated with deficits in three of the models, a finding which is consistent with the association in prior work of proportional representation with balanced budgets.

Somewhat strangely, Logged GDP per capita is in the expected, positive direction in one model, in the negative direction in another, and it does not seem to have any impact in most of the models. This result may be related to the fact that nearly all of the world's presidential systems are in developing countries, and so development level may not be a significant driver in this dataset (and note that the variable is important and strongly significant in the pooled models, which include more OECD countries). Not surprisingly, the variable $\triangle G D P$ is positive and strongly significant in nearly all the models, suggesting that countries experiencing recession are more likely to engage in deficit spending. Likewise, Election Year is positive and significant, likely picking up on the efforts of governments to balance their finances after the overspending that can occur in an election year; this result provides strong support for the political-business cycle. ${ }^{17}$ The variable $\Delta$ Exchange Rate is also an important determinant of the budget balance, with budget surpluses more likely in periods of currency depreciation. This relationship is likely due to the declining debt burden faced by governments in such circumstances. Finally, and unexpectedly, countries with a higher percentage of their populations over the age of 64 are less likely to run a budget deficit. This finding may result from the fact that government social insurance schemes for the elderly are not fully developed in most parts of the world, and so having a larger elderly population may not be the fiscal burden in many places that it is in Europe. In addition, countries with a younger population may be obliged to spend more on education than those which are graying.

\footnotetext{
${ }^{17}$ It is also interesting to note that there is considerably less evidence for a political-business cycle among the parliamentary systems included in Model 14. Given the lack of a fixed timetable for parliamentary elections, this result makes sense. Governments in parliamentary systems can simply call elections in good economic times rather than having to create employment growth with fiscal policy.
} 
I conclude my quantitative analysis with one model (Model 13) that includes both presidential and parliamentary democracies, and another (Model 14) that examines only parliamentary democracies. My purpose in estimating these models is to reproduce the original fragmentation-deficit finding from the literature (which typically pools presidential and parliamentary regimes but which I argue is more appropriate for parliamentary regimes alone) and to test whether presidentialism itself has any impact on budgetary balances. I make use of fixed effects for these models because that approach is the most common one in the previous literature.

I include a Presidential Government dummy in Model 13, which pools both systems, to test the impact of government form on the budget balance. This variable is drawn from the "system" variable of Beck et al. (2001), the same variable use to restrict the previous models to only presidential systems. In addition, I use the same Unified Government variable as before to test the prior literature's link between low fragmentation and fiscal responsibility. For parliamentary systems, this variable measures whether the prime minister's party controls a majority of seats in parliament (as is generally the case in Westminster systems), while in presidential systems it measures (as we have seen) whether the president's party controls a majority in the legislature. As a result, the variable picks up well on the underlying concept of single party dominance overcoming the common pooled resource and veto player problems inherent in the budget process.

Looking first at Model 13, my results indicate that there is no statistically significant difference in budget balances between presidential and parliamentary democracies. This result seems to contrast with Cheibub (2006) and Franzese (2002) and to support Persson and Tabellini (2003), although my focus in this article is not on estimating the impact of parliamentary versus 
presidential government. Interestingly, however, the Unified Government variable is in the expected direction and strongly significant, as has been found in the prior literature. It is worth asking, however, whether that finding is attributable to both the parliamentary and presidential systems included in the model. Model 14 considers only parliamentary systems, and in this operationalization, Unified Government (which now only measures whether the prime minister's party controls a majority of seats in parliament) loses statistical significance, but only slightly. This finding provides some support that the logic of the prior literature holds for parliamentary systems alone. That said, when legislative fractionalization is considered in this model separately from unified government (not shown here for space reasons), there is mixed evidence that it can sometimes improve budget balances, something not anticipated in prior research. As a result, it appears that the prior literature may be basically correct but incomplete in its characterization of parliamentary systems. It may well be, for example, that a curvilinear relationship exists between party fragmentation and budget balances, perhaps because high fragmentation parliamentary systems are more likely to use fiscal pacts (see Hallerberg 2004). A more complete study of parliamentary systems would be beyond the scope of this project, but future research will hopefully delve more deeply into the parliamentary budget process to further refine the arguments that have gone before.

\section{Conclusions}

The insights generated by prior studies on the political economy of deficit spending are impressive but incomplete. Theories identifying a causal relationship between political fragmentation and budget deficits, the primary insight of the literature, are largely based on the logic of parliamentary democracy. In presidential systems, where an independently elected head 
of state dominates the executive, a linear connection between legislative or government fragmentation and overspending seems unlikely.

For that reason, I develop in this article the first theory (to my knowledge) linking political fragmentation with budget deficits specifically for presidential institutions. I argue that presidential democracies should be better able to balance their budgets when government is unified than when it is divided. Furthermore, I contend that, when government is divided, greater party fragmentation in the assembly will facilitate fiscal responsibility by empowering the elected president. I test this theory with a dataset of all presidential democracies from 1976 to 2007 contingent of data availability. The results provide solid evidence for my contentions and even indicate that the effects of legislative fragmentation under conditions of divided presidential government are greater than expected. They also help pull developing countries and diverse democratic institutions into a literature that has centered on explaining the behavior of wealthy, parliamentary systems.

Perhaps more significantly, however, the project underlines the wisdom of considering presidential systems separately when seeking to understand the role of legislative institutions in policy outcomes. While our understanding of the role of party fragmentation has developed most fully in the budgetary politics literature, there is evidence in prior research that highly divided party systems can matter in other arenas as well. For in example, Haggard and Kaufman (1995) associate party fragmentation with an impaired ability to engage in economic reform. Similarly, Ehrlich (2007) finds that such fragmentation is associated with trade protection crossnationally, and Mukherjee (2003) links it with a growth in the provision of private versus public goods. The logic underlying all of these arguments is similar to the one identified in the budget literature, and for that reason it seems likely that the unique separation of executive and 
legislative power in presidential systems should be taken into account in considering these policy arenas as well.

Finally, within the literature on presidential democracy itself, the project forces a reconsideration of which types are institutional arrangements produce the most desired outcomes. Traditionally, scholars of presidentialism have followed Mainwaring (1993) in seeing legislative fragmentation as undesirable, something that makes presidential regimes more prone to breakdown and a variety of other ills. If my argument is to be believed, however, fragmentation is only problematic for good policy-making insofar as it produces consistently divided government. Once government is divided, however, fragmentation can actually contribute to the provision of public goods. Whether this relationship holds for Mainwaring's primary concern - regime breakdown - has yet to be determined, but there is at least reason to believe that it should hold in a wide variety of policy areas. For that reason, future research could usefully examine how party fragmentation and divided government interact in presidential democracies to influence many of those countries' most important decisions. 


\section{References}

Alesina, Alberto and Allan Drazen. 1991. Why are Stabilizations Delayed? American Economic Review 81 (5): 1170-1189.

Alt, James E. and Robert C. Lowry. 2000. A Dynamic Model of state Budget Outcomes under Divided Partisan Government. Journal of Politics 62 (4): 1035-1070.

Baldez, Lisa and John M. Carey. 1999. Presidential Agenda Control and Spending Policy: Lessons from General Pinochet's Constitution. American Journal of Political Science 43 (1): $29-55$.

Barro, Robert J. 1979. On the Determination of the Public Debt. Journal of Political Economy 87 (5): 940-71.

Beck, Nathaniel and Jonathon N. Katz. 1995. What To Do (and Not To Do) with Time-Series Cross-Section Data. American Political Science Review 89 (3): 634-647.

Beck, Thorsten, George Clarke, Alberto Groff, Philip Keeper, and Patrick Walsh. 2001. New Tools in Comparative Political Economy: The Database of Political Institutions. World Bank Economic Review 15 (1): 165-176.

Carey, John M and Matthew Soberg Shugart. 1995. Incentives to Cultivate a Personal Vote: A Rank Ordering of Electoral Formulas. Electoral Studies 14(4): 417-439.

Carey, John M and Matthew Soberg Shugart, eds. 1998. Executive Decree Authority. New York: Cambridge University Press.

Cheibub, José Antonio. 2006. Presidentialism, Electoral Identifiability, and Budget Balances in Democratic Systems. American Political Science Review 100 (3): 353-368.

Cheibub, José Antonio. 2007. Presidentialism, Parliamentarism, and Democracy. New York: Cambridge University Press.

Edin, Per-Anders and Henry Ohlsson. 1991. Political Determinants and Budget Deficits: Coalition Effects versus Minority Effects. European Economic Review 35: 1597-1603.

Ehrlich, Sean. 2007. Access to Protection: Domestic Institutions and Trade Policy in Democracies. International Organization 61 (3): 571-605.

Franzese, Robert. 2002. Macroeconomic Policies of Developed Democracies. Ann Arbor: University of Michigan Press.

Gale, William G. and Peter R. Orszag. 2003. Economic Effects of Sustained Budget Deficits. Working Paper, Tax Policy Center, the Brookings Institution, Washington, DC. 
González, Luis Edouardo and Charles Guy Gillespie. 1994. Presidentialism and Democratic Security in Uruguay. In Juan J. Linz and Arturo Valenzuela, eds., The Failure of Presidential Democracy. Baltimore: Johns Hopkins University Press.

Greene, Willliam H. 2007. Econometric Analysis. New York: Prentice Hall.

Grilli, Vittorio, Donato Masciandaro, and Guido Tabellini. 1991. Political and Monetary Institutions and Public Financial Policies in the Industrial Democracies. Economic Policy 6: 341-92.

Haggard, Stephan and Robert R. Kaufmann. 1995. The Political Economy of Democratic Transitions. Princeton, N.J.: Princeton University Press.

Hahm, Sung Deuk, Mark S. Kamlet, and David C. Mowery. 1996. The Political Economy of Deficit Spending in Nine Industrialized Parliamentary Democracies: The Role of Fiscal Institutions. Comparative Political Studies 29: 52-77.

Hallerberg, Mark. 2004. Domestic Budgets in a United Europe. Ithaca: Cornell University Press.

Hallerberg, Mark and Patrik Marier. 2004. Executive Authority, the Personal Vote, and Budget Discipline in Latin American and Caribbean Countries. American Journal of Political Science 48 (3): 571-587.

Hallerberg, Mark and Jürgen von Hagen. 1999. Electoral Institutions, Cabinet Negotiations, and Budget Deficits within the European Union. In Poterba and von Hagen 1999, 209-32.

Hankla, Charles R. 2006. "Party Strength and International Trade: A Cross National Analysis." Comparative Political Studies 39 (9): 1133-1156.

Henisz, Witold Jerzy. 2003. Political Constraints Dataset and Codebook. Available: http://www-management.wharton.upenn.edu/henisz/.

Hibbs, Douglas A., Jr. 1977. Political Parties and Macroeconomic Policy. American Political Science Review 71: 1467-1487.

Huber, John D. 1996. The Vote of Confidence in Parliamentary Democracies. American Political Science Review 90 (2): 269-282.

International Monetary Fund. 2006. International Financial Statistics.

International Monetary Fund. 2011. International Financial Statistics. Available from www.imf.org.

Jemio, Luis Carlos. 2001. Debt, Crisis, and Reform in Bolivia: Biting the Bullet. New York: Palgrave. 
Jones, Mark P. 1995. Electoral Laws and the Survival of Presidential Democracies. Notre Dame: University of Notre Dame Press.

Karol, David. 2000. Divided Government and U.S. Trade Policy: Much Ado About Nothing? International Organization 54 (4): 825-844.

Kontopoulos, Yianos and Roberto Perotti. 1999. Government Fragmentation and Fiscal Policy Outcomes: Evidence from OECD Countries. In Poterba and von Hagen 1999, 81-102.

Krause, George A. 2000. Partisan and Ideological Sources of Fiscal Deficits in the United States. American Journal of Political Science 44 (3): 541-559.

Laakso, Markku and Rein Taagepera. 1979. 'Effective' Number of Parties: A Measure with Application to Western Europe. Comparative Political Studies 12 (1): 3-27.

Lienert, Ian. 1997. Who Controls the Budget: The Legislature or the Executive? IMF Working Paper WP/05/115.

Linz, Juan J. 1990. The Perils of Presidentialism. Journal of Democracy 1 (1): 59-69.

Lipset, Seymour Martin and Stein Rokkan. 1967. Party Systems and Voter Alignments: CrossNational Perspectives. New York: The Free Press.

Maddala, G. S. and Shaowen Wu. 1999. A Comparative Study of Unit Root Tests with Panel Data and a New Simple Test. Oxford Bulletin of Economics and Statistic, Special Issue.

Mainwaring, Scott. 1993. Presidentialism, Multipartism, and Democracy: The Difficult Combination. Comparative Political Studies 26(2): 198-228.

Mainwaring, Scott. 1999. Rethinking Party Systems in the Third Wave of Democratization: The Case of Brazil. Stanford: Stanford University Press.

Malloy, James M. and Gamarra. 1988. Revolution and Reaction: Bolivia, 1964-1985. New Brunswick: Transaction Books.

Marshall, Monty G. and Keith Jaggers. 2007. Polity IV Project: Political Regime Characteristics and Transitions, 1800-2006. Dataset Users Manuel. College Park: University of Maryland, College Park.

Mukherjee, Bumba. 2003. Political Parties and the Size of Government in Multiparty Legislatures: Examining Cross-Country and Panel Data Evidence. Comparative Political Studies 36(6): 699-728.

Nooruddin, Irfan. 2011. Coalition Politics and Economic Development: Credibility and the Strength of Weak Governments. New York: Cambridge University Press. 
Oatley, Thomas. 1999. How Constraining is Mobile Capital? The Partisan Hypothesis in an Open Economy. American Journal of Political Science 43 (4): 1002-27.

O’Halloran, Sharyn. 1994. Politics, Process, and American Trade Policy. Ann Arbor: The University of Michagen Press.

Perotti, R. and Kontopolous, Y. 2002. Fragmented fiscal policy. Journal of Public Economics, 86(2): 191-222.

Persson, Torsten and Guido Tabellini. 2003. The Economic Effects of Constitutions. Cambridge: The MIT Press.

Poterba, James and Jürgen von Hagen, eds. 1999. Fiscal Institutions and Fiscal Performance. Chicago: University of Chicago Press.

Rogowski, Ronald. 1987. Trade and the Variety of Democratic Institutions. International Organization 41 (2): 202-223.

Roubini, Nouriel and Jeffrey Sachs. 1989. Government spending and budget deficits in the industrial countries. Economic Policy 8: 99-132.

Shugart, Matthew Soberg and John M. Carey. 1992. Presidents and Assemblies: Constitutional Design and Electoral Dynamics. Cambridge: Cambridge University Press.

Stein, Ernesto, Ernesto Talvi and Alejandro Grisanti. 1999. Institutional arrangements and fiscal performance: The Latin American experience. In Poterba and von Hagen 1999, 103-133.

Tsebelis, George. 2002. Veto Players: How Political Institutions Work. New York: Princeton University Press.

Velasco, Andrés. 1997. Debts and Deficits with Fragmented Fiscal Policymaking. NBER Working Paper \# W6286.

Volkerink, Bjørn and Jakob de Haan. 2001. Fragmented Government Effects of Fiscal Policy: New Evidence. Public Choice 109: 221-242.

Wehner, Joachim. 2006. Assessing the Power of the Purse: An Index of Legislative Budget Institutions. Political Studies 54: 767-785.

Wehner, Joachim. 2010. Legislatures and the Budget Process: The Myth of Fiscal Control. New York: Palgrave McMillan.

World Bank. 2008. World Development Indicators. Washington, DC: The World Bank.

Yellen, Janet. 1989. Symposium on the Budget Deficit. Journal of Economic Perspectives 3(2): 17-21. 
Table 1: Country-Years included in the Primary Model (by region, only democratic and presidential country years with available data included)

United States, 1978-2006; Haiti 1995-1999; Dominican Republic, 1979-2007; Mexico 19982000; Guatemala, 1997-2006; Honduras, 1983-2007; El Salvador, 1985-2007; Nicaragua, 19912007; Costa Rica, 1976-2007; Panama, 1991-2001; Colombia, 1976-2003; Venezuela, 19762005; Guyana, 1993-1997; Ecuador, 1981-2000; Peru, 1982-1992, 2002-2007; Brazil, 19862007; Bolivia, 1986-2007; Paraguay, 1993-2007; Chile, 1991-2007; Argentina, 1988-2004; Uruguay, 1986-2007

Poland, 1995-2007; Hungary, 1991; Croatia, 2001; Cyprus, 1978-2000; Bulgaria, 1993-2002; Moldova, 1997-2007; Estonia, 1995-2007; Lithuania, 1994-2007; Ukraine, 2000-2007; Georgia, 2005-2007

Gambia, 1978-1982, 1990-1993; Mali, 1994-2003; Senegal, 2001; Niger, 2006; Ghana, 1981, 2002-2007; Kenya 2003-2007; Zambia, 1992-1996; South Africa, 1995-2007; Namibia, 19922007; Madagascar, 1994-2007; Lebanon, 2006-2007; Israel, 1998-2007

Mongolia, 1994-2007; South Korea, 1989-2007; Sri Lanka, 2002-2003, 2007; Philippines, 19892007; Indonesia, 2000-2007 
Table 2: Summary Statistics

\begin{tabular}{|c|c|c|c|c|c|}
\hline Variable & How Computed & Mean & Range & $\begin{array}{c}\text { St. } \\
\text { Dev. }\end{array}$ & $\begin{array}{c}\text { Expectations } \\
\text { (Y=Budget } \\
\text { Surplus/GDP) }\end{array}$ \\
\hline Budget Balance/GDP & $\begin{array}{l}\text { Total National Budget Balance divided by GDP } \\
\text { X } 100 \text { (Source: World Bank 2008, IMF 2011, } \\
\text { IMF 2006) }\end{array}$ & -1.86 & -18.5 to 19.8 & 3.35 & N/A \\
\hline Budgbal & $\begin{array}{l}\text { Total National Budget Balance divided by GDP } \\
\text { X } 100 \text { (Source: Cheibub 2006) }\end{array}$ & -2.19 & -16.1 to 5.48 & 3.17 & N/A \\
\hline Unified Government & $\begin{array}{l}\text { "1" when party of president controls all relevant } \\
\text { legislative houses (Lagged) (Source: Beck et al. } \\
\text { 2001) }\end{array}$ & .432 & Dummy & .496 & Positive \\
\hline $\begin{array}{l}\text { Divided Government High } \\
\text { Fractionalization }\end{array}$ & $\begin{array}{l}\text { "1" when Unified Government is } 0 \text { and } \\
\text { Legislative Fractionalization is greater than } .67 \\
\text { (Lagged) }\end{array}$ & .339 & Dummy & .474 & Positive \\
\hline Legislative Fractionalization & $\begin{array}{l}\text { Probability that any two lower house legislators } \\
\text { come from different parties (Lagged) (Source: } \\
\text { Beck et al. 2001) }\end{array}$ & .622 & 0 to .928 & .162 & $\begin{array}{c}\text { Positive (as part } \\
\text { of interaction) }\end{array}$ \\
\hline $\begin{array}{l}\text { Unified Government } X \\
\text { Legislative Fractionalization }\end{array}$ & $\begin{array}{l}\text { Interaction of Unified Government and } \\
\text { Legislative Fractionalization (Lagged) }\end{array}$ & .229 & 0 to .879 & .283 & Negative \\
\hline Leftist Government & $\begin{array}{l}\text { "1" when government is leftist (Lagged) } \\
\text { (Source: Beck et al. 2001) }\end{array}$ & .278 & Dummy & .448 & Negative \\
\hline Govt Consumption / GDP & $\begin{array}{l}\text { Government Consumption divided by GDP X } \\
100 \text { (Lagged) (Source: World Bank 2008) }\end{array}$ & 14.1 & 2.90 to 46.0 & 5.64 & Negative \\
\hline$\Delta \mathrm{GDP}$ & $\begin{array}{l}\text { Annual percentage change in GDP (Lagged) } \\
\text { (Source: World Bank 2008) }\end{array}$ & 3.51 & -16.2 to 18.3 & 4.02 & Positive \\
\hline Pop over 64 & $\begin{array}{l}\text { Percent of population over } 64 \text { years old } \\
\text { (Lagged) (Source: World Bank 2008) }\end{array}$ & 6.51 & 2.66 to 16.8 & 3.78 & Negative \\
\hline Plurality Electoral System & $\begin{array}{l}\text { "1" when lower house electoral system is } \\
\text { plurality (Lagged) (Source: Beck et al. 2001) }\end{array}$ & .478 & Dummy & .500 & Negative \\
\hline Logged GDP per capita & $\begin{array}{l}\text { Natural log of Gross Domestic Product per } \\
\text { capita (Lagged) (Source: World Bank 2008) }\end{array}$ & 7.72 & 5.34 to 10.5 & 1.15 & Positive \\
\hline Election Year & $\begin{array}{l}\text { "1" when election year (Lagged) (Source: Beck } \\
\text { et al. 2001) }\end{array}$ & .254 & Dummy & .435 & Positive \\
\hline$\Delta$ Exchange Rate & $\begin{array}{l}\text { Annual percentage change in exchange rate } \\
\text { with the US Dollar (Lagged) (Source: World } \\
\text { Bank 2008) }\end{array}$ & .885 & -.282 to 139 & 7.02 & Ambiguous \\
\hline Presidential Dominance & $\begin{array}{l}\text { Measure of presidential dominance over } \\
\text { budgets (Lagged) (Source: Cheibub 2006) }\end{array}$ & .654 & Dummy & .476 & Positive \\
\hline Legislative Budget Power & $\begin{array}{l}\text { Measure of legislative control over budgets } \\
\text { (Lagged) (Source: Wehner 2010) }\end{array}$ & .563 & 0 to 1 & .330 & Negative \\
\hline $\begin{array}{l}\text { Party } \\
\text { Decentralization }\end{array}$ & $\begin{array}{l}\text { "2" = free candidate access to ballot } \\
\text { (Lagged) (Source: Hankla 2006) }\end{array}$ & .501 & $0,1,2$ & .748 & Negative \\
\hline Unified Government 2 & $\begin{array}{l}\text { "1" when party of president controls all relevant } \\
\text { legislative houses (Lagged) (Source: computed } \\
\text { from Henisz 2003) }\end{array}$ & .755 & Dummy & .430 & Positive \\
\hline $\begin{array}{l}\text { Divided Government High } \\
\text { Fractionalization } 2\end{array}$ & $\begin{array}{l}\text { "1" when Unified Government } 2 \text { is } 0 \text { and } \\
\text { Legislative Fractionalization (taken from } \\
\text { Henisz 2003) is greater than } .67 \text { (Lagged) }\end{array}$ & .124 & Dummy & .330 & Positive \\
\hline Presidential Government & $\begin{array}{l}\text { "1" = Presidential System (Lagged) (Source: } \\
\text { Beck et al. 2001) }\end{array}$ & .444 & Dummy & .497 & $\begin{array}{c}\text { Positive } \\
\text { (used in pooled } \\
\text { models) }\end{array}$ \\
\hline Regional Dummies & Series of dummies for each world region & N/A & N/A & N/A & $\begin{array}{l}\text { Included in all } \\
\text { non-fixed } \\
\text { effects models }\end{array}$ \\
\hline
\end{tabular}


Table 3

Dependent Variable $=$ Budget Surplus/GDP

\begin{tabular}{|c|c|c|c|c|c|c|c|}
\hline Variable & $\begin{array}{c}\text { Model 1 } \\
(\mathrm{N}=623) \\
\text { PCSE } \\
\text { All Pres } \\
\text { Systems }\end{array}$ & $\begin{array}{c}\text { Model 2 } \\
(\mathrm{N}=623) \\
\text { Robust } \\
\text { Regression }\end{array}$ & $\begin{array}{c}\text { Model } 3 \\
\text { (N=623) } \\
\text { Fixed } \\
\text { Effects } \\
\text { All Pres } \\
\text { Systems }\end{array}$ & $\begin{array}{c}\text { Model } 4 \\
(\mathrm{~N}=623) \\
\text { PCSE } \\
\text { All Pres } \\
\text { Systems }\end{array}$ & $\begin{array}{c}\text { Model 5 } \\
(\mathrm{N}=563) \\
\text { PCSE } \\
\text { All Pres } \\
\text { Systems }\end{array}$ & $\begin{array}{c}\text { Model } 6 \\
\text { (N=382) } \\
\text { PCSE } \\
\text { All Pres } \\
\text { Systems }\end{array}$ & $\begin{array}{c}\text { Model } 7 \\
(\mathrm{~N}=376) \\
\text { PCSE } \\
\text { All Pres } \\
\text { Systems }\end{array}$ \\
\hline $\begin{array}{l}\text { Lagged Dependent } \\
\text { Variable }\end{array}$ & $\begin{array}{l}.380 * * * \\
(.070)\end{array}$ & $\begin{array}{l}.659 * * * \\
(.017)\end{array}$ & $\begin{array}{c}.233 * * * \\
(.033)\end{array}$ & $\begin{array}{l}.373 * * * \\
(.069)\end{array}$ & $\begin{array}{l}.340 * * * \\
(.074)\end{array}$ & $\begin{array}{l}.272 * * * \\
(.086)\end{array}$ & $\begin{array}{l}.285 * * * \\
(.086)\end{array}$ \\
\hline $\begin{array}{l}\text { Divided Government High } \\
\text { Fractionalization }\end{array}$ & $\begin{array}{c}.896 * * * \\
(.331) \\
\end{array}$ & $\begin{array}{l}.532 * * * \\
(.195)\end{array}$ & $\begin{array}{l}.605^{1} \\
(.403) \\
\end{array}$ & & $\begin{array}{l}.558^{2} \\
(.381) \\
\end{array}$ & $\begin{array}{l}.834^{3} \\
(.550) \\
\end{array}$ & $\begin{array}{l}1.09 * \\
(.575) \\
\end{array}$ \\
\hline Unified Government & $\begin{array}{l}.879 * * * \\
(.264)\end{array}$ & $\begin{array}{l}.487 * * \\
(.191)\end{array}$ & $\begin{array}{l}.699 * \\
(.367)\end{array}$ & $\begin{array}{c}3.53 * * * \\
(.944)\end{array}$ & $\begin{array}{l}.664 * * \\
(.308)\end{array}$ & $\begin{array}{l}.947 * * \\
(.454)\end{array}$ & $\begin{array}{l}.675^{*} \\
(.353)\end{array}$ \\
\hline $\begin{array}{l}\text { Unified Government } \mathrm{X} \\
\text { Legislative } \\
\text { Fractionalization }\end{array}$ & & & & $\begin{array}{l}-4.56 * * * \\
(1.56)\end{array}$ & & & \\
\hline $\begin{array}{l}\text { Legislative } \\
\text { Fractionalization }\end{array}$ & & & & $\begin{array}{c}4.67 * * * \\
(1.17) \\
\end{array}$ & & & \\
\hline Party Decentralization & & & & & $\begin{array}{c}-.530 * * * \\
(.125)\end{array}$ & & \\
\hline Leftist Government & $\begin{array}{l}.110 \\
(.279) \\
\end{array}$ & $\begin{array}{l}-.023 \\
(.171) \\
\end{array}$ & $\begin{array}{c}.429 \\
(.359) \\
\end{array}$ & $\begin{array}{c}069 \\
(.262) \\
\end{array}$ & $\begin{array}{l}.230 \\
(.283) \\
\end{array}$ & $\begin{array}{l}.742 * \\
(.380) \\
\end{array}$ & $\begin{array}{r}.220 \\
(.351) \\
\end{array}$ \\
\hline $\begin{array}{l}\text { Government Consumption } \\
\text { / GDP }\end{array}$ & $\begin{array}{l}-.013 \\
(.035)\end{array}$ & $\begin{array}{l}-.027 * \\
(.016) \\
\end{array}$ & $\begin{array}{l}-.051 \\
(.037) \\
\end{array}$ & $\begin{array}{l}-.015 \\
(.034)\end{array}$ & $\begin{array}{c}-.021 \\
(.035)\end{array}$ & $\begin{array}{l}-.020 \\
(.060) \\
\end{array}$ & $\begin{array}{l}-.043 \\
(.062) \\
\end{array}$ \\
\hline$\Delta \mathrm{GDP}$ & $\begin{array}{c}.078 * * * \\
(.027)\end{array}$ & $\begin{array}{l}.029 * \\
(.018) \\
\end{array}$ & $\begin{array}{l}.058 * \\
(.030) \\
\end{array}$ & $\begin{array}{c}.075 * * * \\
(.026)\end{array}$ & $\begin{array}{c}.060 * * \\
(.026)\end{array}$ & $\begin{array}{c}.035 \\
(.039) \\
\end{array}$ & $\begin{array}{l}.061 * \\
(.034) \\
\end{array}$ \\
\hline Pop over 64 & $\begin{array}{l}.104 * * \\
(.047)\end{array}$ & $\begin{array}{c}.031 \\
(.035) \\
\end{array}$ & $\begin{array}{c}.804 * * * \\
(.272)\end{array}$ & $\begin{array}{l}.106^{* *} \\
(.046)\end{array}$ & $\begin{array}{l}.111 * * \\
(.053)\end{array}$ & $\begin{array}{l}.183^{* *} \\
(.080)\end{array}$ & $\begin{array}{l}-.034 \\
(.061) \\
\end{array}$ \\
\hline Plurality Electoral System & $\begin{array}{l}-.204 \\
(.281) \\
\end{array}$ & $\begin{array}{l}-.220 \\
(.128)\end{array}$ & $\begin{array}{c}-2.66 * * \\
(1.21)\end{array}$ & $\begin{array}{l}-.198 \\
(.267)\end{array}$ & $\begin{array}{l}-.063 \\
(.327) \\
\end{array}$ & $\begin{array}{c}-.894^{*} \\
(.478)\end{array}$ & $\begin{array}{l}-.323 \\
(.513) \\
\end{array}$ \\
\hline Logged GDP per capita & $\begin{array}{l}-.049 \\
(.126) \\
\end{array}$ & $\begin{array}{c}.050 \\
(.088) \\
\end{array}$ & $\begin{array}{l}-.856 \\
(1.17)\end{array}$ & $\begin{array}{l}-.002 \\
(.127)\end{array}$ & $\begin{array}{l}-.067 \\
(.130)\end{array}$ & $\begin{array}{l}-.071 \\
(.233) \\
\end{array}$ & $\begin{array}{l}.611 * * \\
(.295)\end{array}$ \\
\hline Election Year & $\begin{array}{l}.608 * * \\
(.244)\end{array}$ & $\begin{array}{l}.335 * * \\
(.157)\end{array}$ & $\begin{array}{l}.587 * * \\
(.252)\end{array}$ & $\begin{array}{c}.636 * * * \\
(.245)\end{array}$ & $\begin{array}{l}.502 * * \\
(.239)\end{array}$ & $\begin{array}{c}.491 \\
(.348) \\
\end{array}$ & $\begin{array}{c}.442 \\
(.321)\end{array}$ \\
\hline$\Delta$ Exchange Rate & $\begin{array}{c}.123 * * * \\
(.029)\end{array}$ & $\begin{array}{c}.236 * * * \\
(.011)\end{array}$ & $\begin{array}{c}.095 * * * \\
(.018)\end{array}$ & $\begin{array}{c}.123 * * * \\
(.029)\end{array}$ & $\begin{array}{c}.113 * * * \\
(.026)\end{array}$ & $\begin{array}{c}.095 * * * \\
(.028)\end{array}$ & $\begin{array}{c}.107 * * * \\
(.028)\end{array}$ \\
\hline $\begin{array}{l}\text { Presidential Dominance } \\
\text { (Cheibub) }\end{array}$ & & & & & & & $\begin{array}{l}.878 * * \\
(.432) \\
\end{array}$ \\
\hline $\begin{array}{l}\text { Legislative Budget Power } \\
\text { (Wehner) }\end{array}$ & & & & & & $\begin{array}{c}-1.43 * * \\
(.650)\end{array}$ & \\
\hline $\mathrm{R}^{\wedge} 2$ & .309 & N/A & .040 & .314 & .295 & .280 & .273 \\
\hline
\end{tabular}

$* * * \mathrm{p}<.01, * * \mathrm{p}<.05,{ }^{*} \mathrm{p}<.10,{ }^{1} \mathrm{p}=.134,{ }^{2} \mathrm{p}=.143,{ }^{3} \mathrm{p}=.129$. All tests are 2-tailed. Standard errors are in parenthesis. 
Table 4

Dependent Variable $=$ Budget Surplus/GDP unless otherwise stated

\begin{tabular}{|c|c|c|c|c|c|c|c|}
\hline Variable & $\begin{array}{c}\text { Model } 8 \\
(\mathrm{~N}=636) \\
\text { PCSE } \\
\text { All Pres } \\
\text { Systems }\end{array}$ & $\begin{array}{c}\text { Model } 9 \\
\text { Y= } \\
\text { Budgbal } \\
\text { (N=415) } \\
\text { PCSE } \\
\text { All Pres } \\
\text { Systems }\end{array}$ & $\begin{array}{c}\text { Model 10 } \\
\text { (N=345) } \\
\text { Pres } \\
\text { Systems } \\
\text { with } \\
\text { Powerful } \\
\text { Legislatures }\end{array}$ & $\begin{array}{c}\text { Model 11 } \\
\text { (N=476) } \\
\text { Pres } \\
\text { Systems } \\
\text { with } \\
\text { Centralized } \\
\text { Parties }\end{array}$ & $\begin{array}{r}\text { Model } 12 \\
(\mathrm{~N}=592) \\
\text { All Pres } \\
\text { Systems }\end{array}$ & $\begin{array}{c}\text { Model 13 } \\
(\mathrm{N}=1424) \\
\text { Fixed } \\
\text { Effects } \\
\text { All } \\
\text { Systems }\end{array}$ & $\begin{array}{c}\text { Model 14 } \\
\text { (N=791) } \\
\text { Fixed } \\
\text { Effects } \\
\text { All Parl } \\
\text { Systems }\end{array}$ \\
\hline $\begin{array}{l}\text { Lagged Dependent } \\
\text { Variable }\end{array}$ & $\begin{array}{l}.331 * * * \\
(.057)\end{array}$ & $\begin{array}{l}.524 * * * \\
(.079)\end{array}$ & $\begin{array}{l}.229 * * * \\
(.086)\end{array}$ & $\begin{array}{l}.297 * * * \\
(.078)\end{array}$ & $\begin{array}{l}.372 * * * \\
(.071)\end{array}$ & $\begin{array}{c}.0003 \\
(.0002)\end{array}$ & $\begin{array}{c}.0003 \\
(.0002)\end{array}$ \\
\hline $\begin{array}{l}\text { Divided Govt High } \\
\text { Fractionalization }\end{array}$ & $\begin{array}{c}.858 * * * \\
(.332)\end{array}$ & $\begin{array}{l}.741 * * \\
(.309)\end{array}$ & $\begin{array}{l}1.36 * * \\
(.561)\end{array}$ & $\begin{array}{l}.489^{2} \\
(.448) \\
\end{array}$ & & & \\
\hline Unified Government & $\begin{array}{l}.985 * * * \\
(.269)\end{array}$ & $\begin{array}{l}.657^{1} \\
(.408) \\
\end{array}$ & $\begin{array}{l}1.39 * * * \\
(.439)\end{array}$ & $\begin{array}{l}.639^{3} \\
(.402) \\
\end{array}$ & & $\begin{array}{l}.771 * * * \\
(.277)\end{array}$ & $\begin{array}{l}.674^{4} \\
(.482)\end{array}$ \\
\hline $\begin{array}{l}\text { Divided Government } \\
\text { High Fractionalization } 2\end{array}$ & & & & & $\begin{array}{l}1.09 * * \\
(.436)\end{array}$ & & \\
\hline Unified Government 2 & & & & & $\begin{array}{l}.507 * * \\
(.245) \\
\end{array}$ & & \\
\hline Presidential Government & & & & & & $\begin{array}{l}-.855 \\
(.878)\end{array}$ & \\
\hline Leftist Government & $\begin{array}{l}.152 \\
(.250) \\
\end{array}$ & $\begin{array}{l}.210 \\
(.328) \\
\end{array}$ & $\begin{array}{c}.603 \\
(.381) \\
\end{array}$ & $\begin{array}{l}.130 \\
(.298) \\
\end{array}$ & $\begin{array}{l}.304 \\
(.283) \\
\end{array}$ & $\begin{array}{c}.657 * * * \\
(.229)\end{array}$ & $\begin{array}{l}.580 * * \\
(.293)\end{array}$ \\
\hline $\begin{array}{l}\text { Government } \\
\text { Consumption / GDP }\end{array}$ & & $\begin{array}{c}.023 \\
(.032)\end{array}$ & $\begin{array}{c}.039 \\
(.054)\end{array}$ & $\begin{array}{l}-.009 \\
(.037)\end{array}$ & $\begin{array}{l}-.031 \\
(.036)\end{array}$ & $\begin{array}{c}-.230 * * * \\
(.035)\end{array}$ & $\begin{array}{c}-.470 * * * \\
(.073)\end{array}$ \\
\hline$\Delta \mathrm{GDP}$ & & $\begin{array}{c}.017 \\
(.036) \\
\end{array}$ & $\begin{array}{c}.048 \\
(.041) \\
\end{array}$ & $\begin{array}{l}.051 * \\
(.027) \\
\end{array}$ & $\begin{array}{l}.057 * * \\
(.026)\end{array}$ & $\begin{array}{l}.066^{* *} \\
(.027)\end{array}$ & $\begin{array}{l}.088 * \\
(.047)\end{array}$ \\
\hline Pop over 64 & $\begin{array}{c}.093 * * * \\
(.035)\end{array}$ & $\begin{array}{l}.133^{*} \\
(.072)\end{array}$ & $\begin{array}{l}.141 * \\
(.080)\end{array}$ & $\begin{array}{c}.084 \\
(.063)\end{array}$ & $\begin{array}{l}.087 * \\
(.050)\end{array}$ & $\begin{array}{c}.579 * * * \\
(.146)\end{array}$ & $\begin{array}{c}.527 * * * \\
(.173)\end{array}$ \\
\hline Plurality Electoral System & $\begin{array}{l}-.106 \\
(.261)\end{array}$ & $\begin{array}{l}-.504 \\
(.352)\end{array}$ & $\begin{array}{c}-1.30 * * * \\
(.497)\end{array}$ & $\begin{array}{c}.340 \\
(.365) \\
\end{array}$ & $\begin{array}{l}-.064 \\
(.301)\end{array}$ & $\begin{array}{l}-1.45 \\
(1.10)\end{array}$ & $\begin{array}{l}5.39 * * \\
(2.11)\end{array}$ \\
\hline Logged GDP per capita & & $\begin{array}{c}-.429 * * \\
(.208)\end{array}$ & $\begin{array}{c}.098 \\
(.235)\end{array}$ & $\begin{array}{c}.155 \\
(.129) \\
\end{array}$ & $\begin{array}{l}-.070 \\
(.138)\end{array}$ & $\begin{array}{c}4.84 * * * \\
(.638)\end{array}$ & $\begin{array}{c}6.58 * * * \\
(.773)\end{array}$ \\
\hline Election Year & $\begin{array}{c}.626 * * * \\
(.242)\end{array}$ & $\begin{array}{l}.456 * * \\
(.228)\end{array}$ & $\begin{array}{c}.576 \\
(.377)\end{array}$ & $\begin{array}{l}.521 * \\
(.298)\end{array}$ & $\begin{array}{l}.496 * * \\
(.243)\end{array}$ & $\begin{array}{c}.286 \\
(.191)\end{array}$ & $\begin{array}{l}.133 \\
(.264)\end{array}$ \\
\hline Logged $\Delta$ Exchange Rate & $\begin{array}{c}.100 * * * \\
(.026)\end{array}$ & $\begin{array}{c}.099 * * * \\
(.031)\end{array}$ & $\begin{array}{c}.079 * * * \\
(.030)\end{array}$ & $\begin{array}{c}.102 * * * \\
(.027)\end{array}$ & $\begin{array}{c}.125 * * * \\
(.023)\end{array}$ & $\begin{array}{l}.045^{* *} \\
(.019) \\
\end{array}$ & $\begin{array}{c}1.60 * * * \\
(.553)\end{array}$ \\
\hline $\mathrm{R}^{\wedge} 2$ & .271 & .433 & .284 & .259 & .289 & .004 & .005 \\
\hline
\end{tabular}

$* * * \mathrm{p}<.01,{ }^{*} \mathrm{p}<.05,{ }^{*} \mathrm{p}<.10,{ }^{1} \mathrm{p}=.108,{ }^{2} \mathrm{p}=.275,{ }^{3} \mathrm{p}=.112,{ }^{4} \mathrm{p}=.162$. All tests are 2-tailed. Standard errors are in parenthesis. 
Figure 1

\section{Effect of Unified Government on Budget Balance Under Different Levels of Legislative Fractionalization (Showing 95\% Confidence Intervals)}

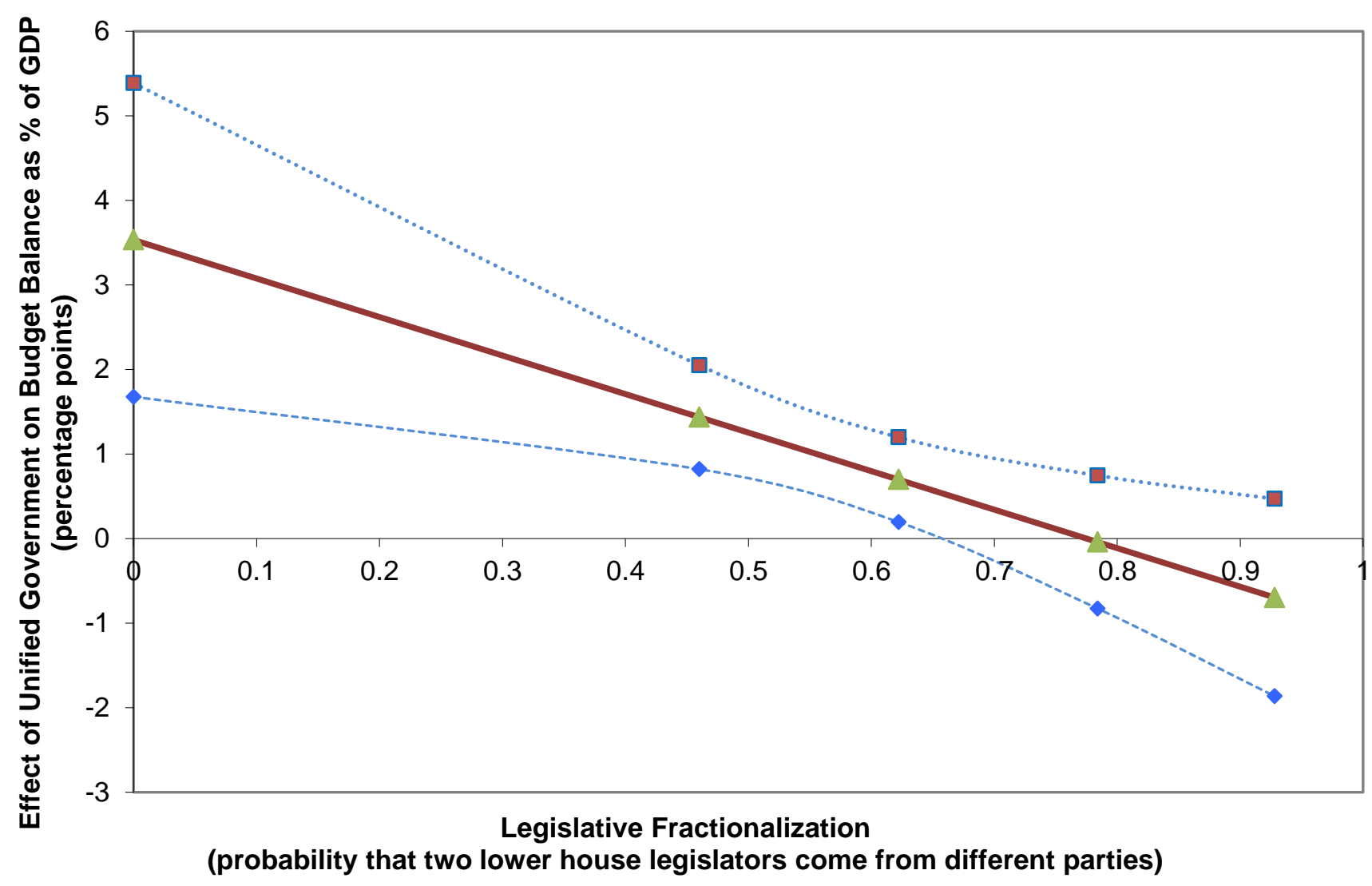


Figure 2

Effect of Legislative Fractionalization on Budget Balance Under Divided and Unified Government (Showing 95\% Confidence Intervals)

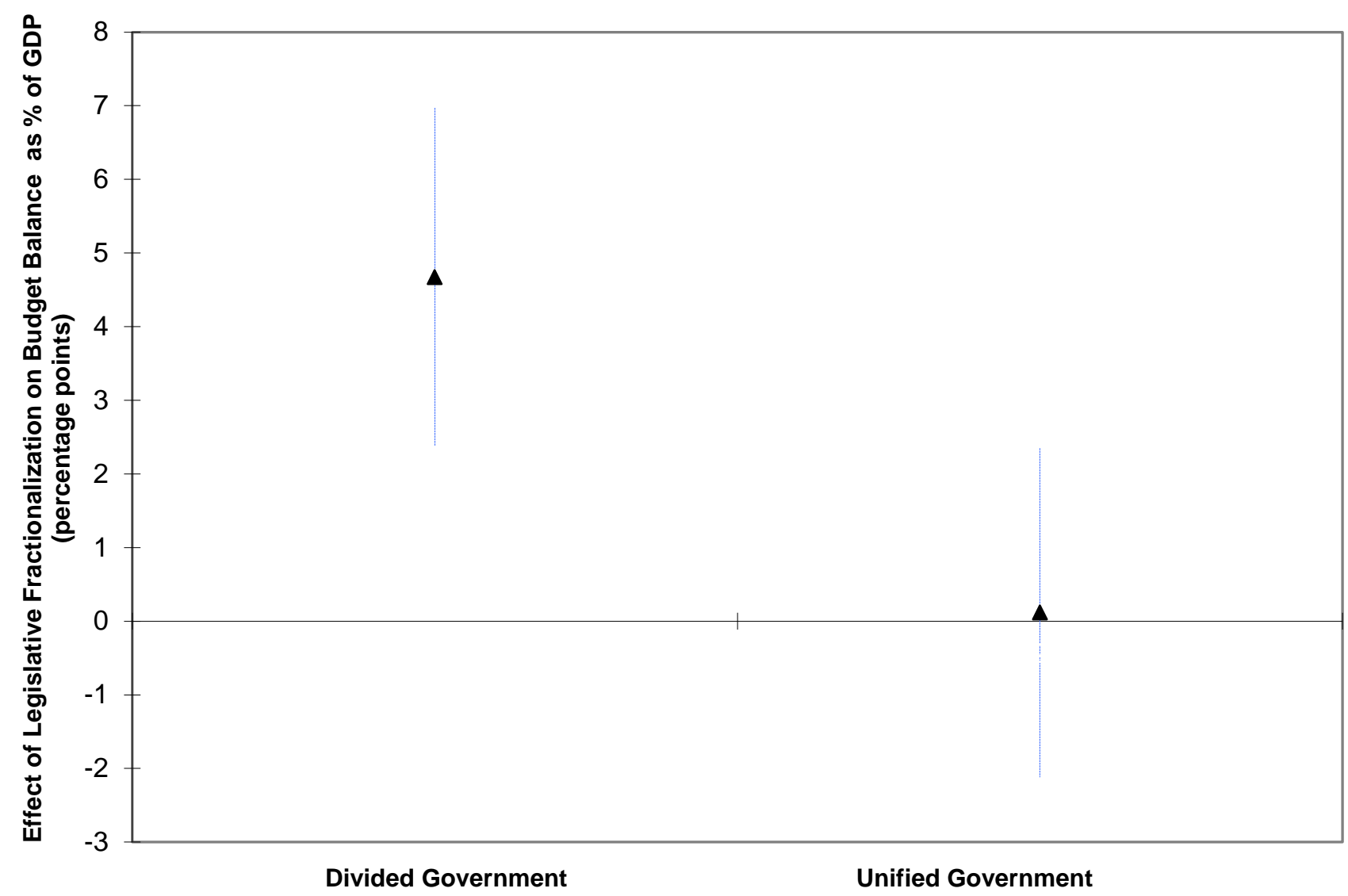

